\title{
Author Correction: Transcriptome and functional analysis reveals hybrid vigor for oil biosynthesis in oil palm
}

\author{
Jingjing Jin ${ }^{1,2,3,4}$, Yanwei Sun ${ }^{1,5}$, Jing Qu ${ }^{1}$, Rahmad syah ${ }^{6}$, Chin-Huat Lim ${ }^{6}$, Yuzer Alfiko ${ }^{6}$, \\ Nur Estya Bte Rahman ${ }^{1}$, Antonius Suwanto ${ }^{6}$, Genhua Yue ${ }^{1}$, Limsoon Wong $\mathbb{D}^{3}$, Nam- \\ Hai Chua² \& Jian Ye $\mathbb{D}^{1,5}$
}

Correction to: Scientific Reports https://doi.org/10.1038/s41598-017-00438-8, published online 27 March 2017

The original version of this Article contained a typographical error in the spelling of the author Nur Estya Bte Rahman, which was incorrectly given as NurEstyaBte Rahman.

In addition Nur Estya Bte Rahman was incorrectly listed as being affiliated with 'R\&D Department, Wilmar International Plantation, Palembang, Indonesia Biotech Lab, Wilmar International, Jakarta, Indonesia. The correct affiliation is listed below:

Temasek Life Sciences Laboratory, National University of Singapore, 1 Research Link, 117604, NUS, Singapore.

These errors have now been corrected in both the PDF and HTML versions of the Article.

(1) Open Access This article is licensed under a Creative Commons Attribution 4.0 International License, which permits use, sharing, adaptation, distribution and reproduction in any medium or format, as long as you give appropriate credit to the original author(s) and the source, provide a link to the Creative Commons license, and indicate if changes were made. The images or other third party material in this article are included in the article's Creative Commons license, unless indicated otherwise in a credit line to the material. If material is not included in the article's Creative Commons license and your intended use is not permitted by statutory regulation or exceeds the permitted use, you will need to obtain permission directly from the copyright holder. To view a copy of this license, visit http://creativecommons.org/licenses/by/4.0/.

(C) The Author(s) 2018

\footnotetext{
${ }^{1}$ Temasek Life Sciences Laboratory, National University of Singapore, 1 Research Link, 117604, NUS, Singapore. ${ }^{2}$ Laboratory of Plant Molecular Biology, Rockefeller University, 1230 York Avenue, New York, NY, 10021, USA. ${ }^{3}$ School of Computing, National University of Singapore, 117417, NUS, Singapore. ${ }^{4}$ China Tobacco Gene Research Center, Zhengzhou Tobacco Research Institute of CNTC, Zhengzhou, Henan, 450001, China. ${ }^{5}$ State Key laboratory of Plant Genomics, Institute of Microbiology, Chinese Academy of Sciences, Beijing, 100101, China. ${ }^{6}$ R\&D Department, Wilmar International Plantation, Palembang, Indonesia Biotech Lab, Wilmar International, Jakarta, Indonesia. Jingjing Jin and Yanwei Sun contributed equally to this work. Correspondence and requests for materials should be addressed to J.Y. (email: jianye@im.ac.cn)
} 